THURSDAY, OCTOBER I3, I870

\section{NATURAL HISTORY SOCIETIES}

I.

XISTING Natural History Societies, or Field Clubs, $F$ may be divided into two classes : those which have already a definite scientific position, and aim especially at working out the flora and fauna of their country or dis. trict ; and those which have for their object the popularising of the various branches of Natural Science, always with due regard to scientific exactness. The first consist chiefly of professed naturalists; the second of intelligent persons who have some desire to gain a little insight into the wonders with which they are surrounded. Some societies combine the two; and these are, perhaps, the most useful of the three classes. Although taking a somewhat lower tone, our second class is to the full as important as the more advanced one; and if by its means our fellowcountrymen obtain even a slight knowledge of some branch of Natural History, something will have been done to diminish in some measure the mass of ignorance on matters connected with Natural Science which still prevails among educated people. Apropos of this, we may mention one instance which has lately come to our knowledge. Some people, of average education and intellect, who had resided for fifteen years in a country district, had brought to them a full-grown larva of the Privet Hawkmoth. Having no idea of its nature,-although one suggested that it was a "locust!"-but a sort of dread of its mysterious appearance, and of the horn on its tail, a council of war was held, and, it being considered too large to "squash," the unfortunate creature was forth with placed in a pail of water, where it remained for eight or ten hours. At the end of this time a naturalist intervened, and the caterpillar was rescued from its bath; when, strange to relate, it positively lived for three or four days, but died while passing into the state of pupa.

Having had some practical experience in the working of more than one local society, and somewhat special opportunities for becoming acquainted with the modus operandi pursued by others, a few notes on some of the more salient points which they presert may be of some interest, and possibly of some use, to those who purpose taking part in establishing such a body. On the present occasion, we will confine ourselves to those societies which, either from the long period for which they have been established, or from other favouing circumstances, have attained a definite position, and are chiefly maintained by experienced naturalists, deferring for a future paper some hints and suggestions on the formation of less pretentious bodies.

One of the most important duties which devolves upon a society or field club possessing a fair proportion of working members, is the investigation of the flora and fauna of the district in which it is placed. Agreeing, as all will do, with Linnæus, that "turpe est in patriâ vivere, et patriam ignorare," it is evident that it is mainly through the agency of such bodies that a knowledge of the Natural History of the country generally is to be obtained. For such purposes there is no plan so satisfactory as that

VOL. II: which is termed "working by sections." On this system, the society is divided into a number of smaller bodies, each having for its object the investigation and reporting upon some one branch, and consisting exclusively of those who are able and willing to devote both time and attention to the subject. Each section has its chairman and secretary, and holds its meetings independently of the remainder of the society. This plan has two advantagesonly those who really work will undertake to join a section, and their meetings are kept free from any hindrance arising from the "drones," who, it must be confessed, are to be found more or less in every society, great or small. Besides, the three or four members forming each section can ailways conveniently meet at each other's houses, a proceeding which could not be so readily carried out if the whole number were assembled for each meeting; and as the societies which have the advantage of a room specially retained for meetings are but few in number, this consideration is not unimportant.

The thorough and convenient investigation of the Natural History of a district, though an important, is not the only duty of a field club; the same body may be of yet greater service in aiding in the publication of the facts which have been collected by its members. In this manner local societies have already done good service to science; thus, in botany alone, we owe to the Tyneside Naturalists' Club, Mr. J. G. Baker's valuable "Flora of Northumberland and Durham;" to the Holmesdale Naturalists' Club, Mr. Brewer's "Flora of Surrey ;" to the Worcestershire Field Club, Mr. Lees' "Botany of Worces. tershire;" while of similar works in preparation we may mention the "Flora of Herefordshire," by the Woolhope Club (of which Part I is already published); that of East Kent, by the East Kent Natural History Society; of Folkestone, by the Folkestone Society; of Berkshire (a much needed contribution to British botany), by the Newbury District Field Club; and many more. The Tyneside naturalists certainly stand first in the value and importance of their published proceedings, which, especially since their union with the Natural History Society of Northumberland, Durham, and Newcastle, have attained a scientific position which renders them indispensable to those who would obtain a complete knowledge of the Natural History of the country at large. As a proof that local matters are not neglected in these volumes, catalogues of the Lepidoptera, Mlollusca, Zoophyta, recent Foraminifera, and Fossils, have been published in them, and also issued separately at a moderate cost ; and the last volume contains a paper on the "Crusticean Fauna of the Salt Marshes," and a "Catalogue of the Aculeate Hymenoptera," of the two counties. We have been thus particular in commenting on these transactions, as they appear to us to afford a very good example of what the publications of the higher class of field clubs ought to be : essentially local, yet at the same time of sufficient general interest to be really valuable contributions to the Natural History of England. Second only to them in importance are the "Proceedings of the Berwickshire Naturalists' Club," of which the sixth volume is now in progress. This society is of especial interest as being the first local field club established in the kingdom.

Another advantage attending the publication of local floras by field clubs, is that by their means the expenses 
attendant upon such works fall less heavily upon those who undertake their compilation, and a fair number of subscribers is more readily obtained. Although much has already been done in publishing such works, there is still much remaining to be done; we could wish, for example, that the Manchester naturalists would publish a new and more complete edition of the "Manchester Flora," and that the Liverpool people would issue in a separate and completed form the flora which appeared in part in their journal. These floras, with that of Birmingham, if carefully worked out, with full references to the older writers, would be of a value second only to that of Trimen and Dyer's "Flora of Middlesex," as showing the influence of cultivation upon the botany of a district.

We must not dismiss the subject of publications without a reference to one or two of those emanating from more recently established societies, which have been favourably received. The Woolhope Club has now issued four volumes, copiously illustrated with photographs and coloured lithographs, the contents of which are of somewhat more general interest than those we have already referred to. This being the case, we can but regret that the volumes are inaccessible to the general public; but a limited number only are printed, which are almost confined in circulation to the members of the club. Noteworthy papers are those on the remarkable trees of Herefordshire (adorned with some exquisite photographs), on the fungi of the county, and on its geology ; while the antiquarian will find some prominence given to archæology. The Malvern Naturalists' transactions are similar in general features to those of the Woolhope Club, and we observe that the two societies vie with each other in the attention they bestow upon edible fungi. The Birmingham Society has just issued the first volume of its proceedings-a very creditable one-which has the additional advantage of being obtainable by outsiders at the moderate cost of half-a-crown. We need not remark further upon this, as a notice of it lately appeared in our columns.

The general arrangement of meetings, \&c., must depend almost entirely upon local circumstances; and the same remark will apply to rules, which should be as few and simple as possible. As we are now speaking only of firmly established bodies, any hints upon these matters are deferred for a second paper.

\section{A WORD ABOUT YALE}

T $\mathrm{HE}$ following account of the Yale University scheme, by Professor J. D. Dana, is taken from the Yale College Conrant:-

I. The Classical or Academic and the Scientific departments (ordinarily called Yale College, and the Sheffield School of Science) are distinct colleges for the undergraduate students of the University-distinct in teachers, scholars, buildings, apparatus, and special working libraries. They have in common a general library, and the officers meet for the discussion of University questions in a common University Faculty.

2. In each college the first two years of the four* are years of preparatory study without optional or elective courses, except perhaps in place of the higher mathema-

* The three-years' course of the Scientific School will probably be made four-years' course within a year or two. tics of the second year. After the close of the second year a number of elective courses are before the student.

3. In the Academic College-whose special subjects of study are the classics, modern languages, mathematics, astronomy, history, intellectual and moral philosophy, political economy, general literature, \&c.- the principles of natural science, physics, and chemistry are taught so far as is necessary to give depth and breadth to an academic education; a general knowledge of the laws or systems of nature, both organic and inorganic, being essential in these days to a true scholar, whatever his purpose in life.

4. In the Scientific College-whose special subjects of study are the various natural sciences, physics, chemistry, mathematics, and the practical applications of these sciences-literary subjects are added, including modern languages (some knowledge of the ancient languages being required for entering), political, moral, and intellectual science, history, physical and political geography, \&c.in order to give in this branch of the University a thorough and well-grounded education, and make the graduate a man of high culture.

5. In the Academic College, optional or elective courses are confined to its special subjects of study: ( $\mathrm{I}$ ) the classics, (2) modern languages, (3) English language and Jiterature, (4) mathematics. None are allowed in the departments of natural, chemical, or physical science, as these subjects are admitted into this college only so far as is necessary to give that breadth and depth to education which every graduate should have.

6. In the Scientific College also, elective courses are confined to its special objects of study-that is, to the natural sciences, physics, geology, metallurgy, mechanics, engineering, \&c.

7. The post-graduate courses of the University comprise many distinct departments in the lines of the Academic and Scientific Colleges. Connected with the former, there are (or may be) courses in Latin, Greek, different Oriental languages, linguistics, English language and literature, history, intellectual philosophy, mathematics, astronomy, \&c. \&c. Connected with the latter there are (or may be): First, in pure science, courses severally in the different physical sciences, general chemistry, organic chemistry, mineralogy, botany, zoology, palæeontology, geology, mathematics, astronomy, \&c.; Secondly, in applied science, courses in civil engineering, mechanical engineering, mining and mining engineering, practical mechanics, metallurgy, agriculture and agricultural chemistry, \&c.

8. The students of the Academic College take, on graduating, the clegree of Bachelor of Arts; and those of the Scientific College that of Bachelor of Philosophy.

The students of the post-graduate courses, after two years of study, in which high scholarship is attained as tested by a rigid examination, take the degree of Doctor of Philosophy; except in the case of students in Civil Engineering, who may receive that of Civil Engineer after one year of study.

The University includes also the Schools of Law, Medicine, Theology, and the Fine Arts. But of these it is not necessary here to speak. Neither of them has, in any part of its curriculum, an undergraduate department analogous to that of the Academic or Scientific Coliege. 